\title{
ARTICLE
}

\section{Converting rain into drinking water: Quality issues and technological advances}

\author{
I. Adler*, K. A. Hudson-Edwards** and L. Campos*
}

* Civil, Environmental and Geomatic Engineering, University College London, Gower Street, WC1E 6BT, UK (E-mail: ilan.adler.09@ucl.ac.uk; l.campos@ucl.ac.uk)

** Dept. of Earth and Planetary Sciences, Birkbeck, Univ. of London, Malet Street, London WC1E 7HX, UK (E-mail: k.hudson-edwards@bbk.ac.uk)

\begin{abstract}
With growing pressures on water supplies worldwide, rainwater harvesting is increasingly seen as a viable option to provide drinking water to an ever expanding population, particularly in developing countries. However, rooftop runoff is not without quality issues. Microbiological and chemical contamination have been detected in several studies, well above local and international guidelines, posing a health risk for consumers. Our research explores the use of silver ions, combined with conventional filtration and settling mechanisms, as a safe and affordable model for purification that can be applied at a small scale. The complete systems are installed and tested in rural communities of a Mexican semi-arid region. Efficiencies up to $99.9 \%$ are achieved in the removal of indicator microorganisms, with a marked exception where cross-contamination from external seepage occurs. Sites without overhanging branches or with relatively clean surfaces show an absence of total coliforms in the untreated runoff, compared with others where values as high as $1650 \mathrm{CFU} / 100 \mathrm{ml}$ are recorded. Thus, given adequate maintenance, the system can successfully deliver high quality drinking water, even when storage is required for long periods of time.
\end{abstract}

\section{KEYWORDS}

Rainwater harvesting; water quality; sustainability; filtration; silver ions

\section{INTRODUCTION}

In a growing number of rural and urban communities in developing countries worldwide, water is either contaminated or not readily available. Changing weather patterns tend to exacerbate the problem, putting undue pressure on already limited supplies, or deteriorating quality in the case of floods. In consequence, rainwater harvesting $(\mathrm{RWH})$ is seen as a sustainable alternative for drinking water, due to its overall good quality and availability, provided adequate storage and treatment is considered (Gould 1999; Meera \& Ahammed 2006). Direct consumption of collected rainwater without any form of purification or treatment is strongly discouraged by the World Health Organization (WHO 1997) due to evidence of microbiological and chemical contamination from both atmospheric deposition and rooftop runoff (Gould \& Nissen-Petersen 1999; Evans et al. 2007). Although in some cases a natural resistance to certain pathogens can emerge on healthy individuals after long-term exposure, outbreaks of gastrointestinal diseases have been specifically linked to rainwater harvesting systems (Lye 2002). Among the pathogens found in rainwater are Salmonella, E. coli, Legionella, Campylobacter (commonly associated with animal faecal matter), as well as protozoans such as Giardia and Cryptosporidium (Simmons et al. 2001; Fewtrell \& Kay 2007).

In this light, proper treatment methods are of paramount importance. At present there are environmental and health concerns with most conventional disinfection methods. Chlorination, for example, can produce harmful substances when in contact with decaying organic matter for a prolonged period, a scenario that may occur regularly in a settling tank or in a typical rainwater cistern (Xie 2004; Mitch et al. 2003). There are also issues with ultraviolet disinfection systems (UV) and Ozone, in terms of the low residual effect in the treated water, thus increasing the possibility of recontamination. Both of these require continuous electric energy to operate. Ozone has also been linked to the formation of carcinogenic by-products such as Aldehydes (Bitton 1994; Xie 2004). Solar disinfection or SODIS, a technique popular in isolated rural areas of developing countries, is also not without limitations, major issues being removal efficiency and possibility of recontamination (Amin \& Han 2009). 
Adler, I; Campos, LC; Hudson-Edwards, KA; (2011) Converting rain into drinking water: Quality issues and technological advances. Water Science and Technology: Water Supply , 11 (6) 659 - 667.

The aim of this study is to determine the potential of an alternative technique for purifying rainwater collected for human consumption. The technology consists of a conventional filtration system coupled with a device that releases silver ions into the water by applying small electrical currents to a pair of electrodes (Figure 1). Silver has been used since time immemorial as a water disinfectant, and is now coming back into the public interest as a safe and efficient technique for water purification (Landau 2007; Lansdown 2006; Gerba \& Thurman 1989). A number of small-scale systems, integrating these technologies, were installed in selected communities throughout the municipality of San Miguel de Allende, located in a semi-arid region (average precipitation: $400-600 \mathrm{~mm} / \mathrm{year}$ ) on the central highlands of Mexico (ESF 2006). The systems, operating mostly in schools and rural clinics, were set up with Government funding and the support of local NGOs to make up for scarce or contaminated supplies.

\section{MATERIALS AND METHODS}

\section{Model description}

The rainwater harvesting systems were installed between 2007 and 2009. They all contain roughly the same components, as outlined below (numbers correspond to Figure 1):

1) First-flush/ settling tank: consisting of a 450 I plastic covered tank

2) Cistern: Varies according to site conditions (Table 1), but mostly made of geomembrane, built overground with a supporting steel mesh structure. When buried, the floor and walls are lined with plastic geomembranes, instead of concrete. In very few cases, 5,000 I plastic tanks are used. All cisterns and tanks are covered to avoid contamination

3) Stainless steel filter to remove particles larger than $100 \mu \mathrm{m}$

4) Silver ionizing unit: A circuit contained in the box supplies a DC voltage, which can be regulated with a knob, to a pair of silver electrodes. The voltage, usually around $5-10 \mathrm{~V}$, alternates every few seconds to provide a balanced decay of each electrode, as the silver ions are released into the passing water.

5) Refillable filters containing a mixture of activated carbon (GAC) and Kinetic Degradation Fluxion (KDF) filtration media

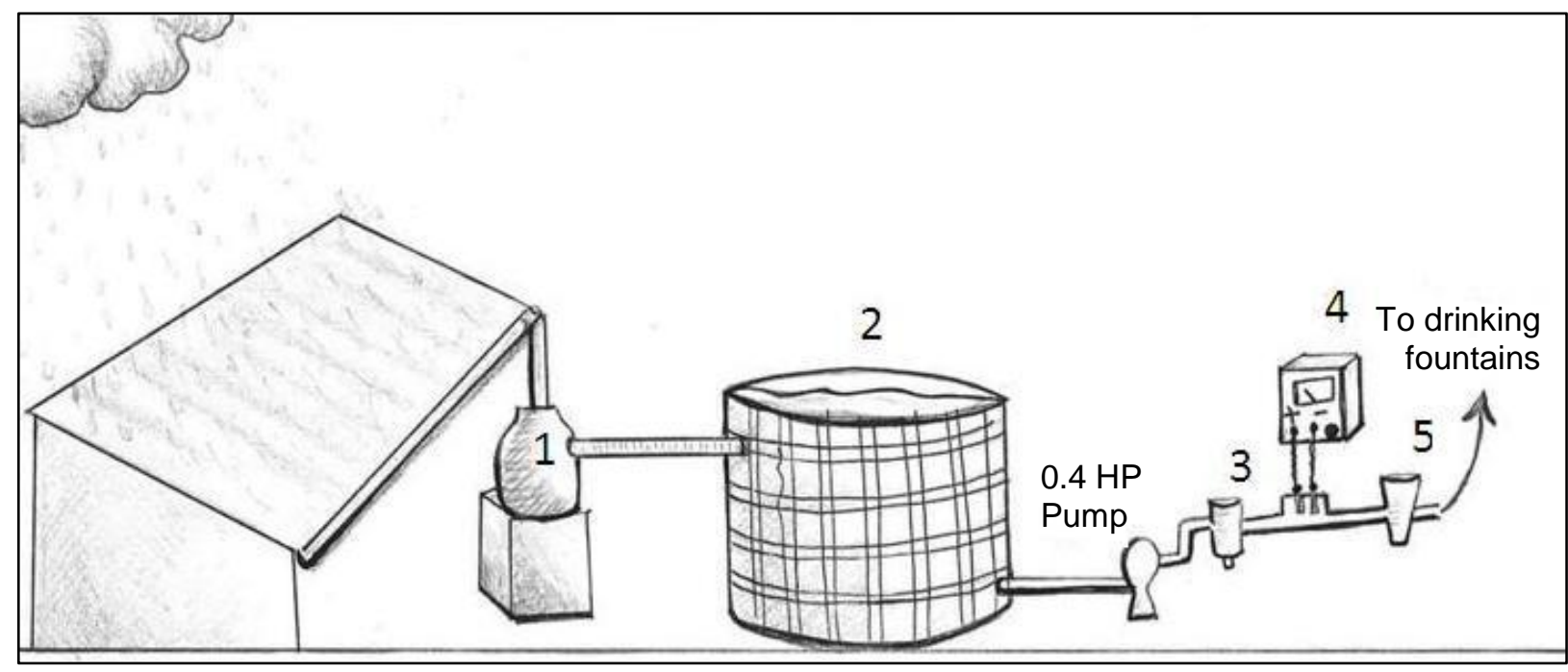

Figure 1. General rainwater system design.

Variations on the general design exist for individual systems, due to site-specific conditions and the fact that some of them were constructed at different periods. Cistern size, for instance, changes according to catchment area and water demand. On sites as \#5, \#7 and \#8 (Table 1), the filters used are larger than the standard 20 -inch $(50 \mathrm{~cm})$ models used on all other sites, in order to accommodate the larger consumption volumes. These are also the only underground cisterns, due to the greater capacity needed.

All of the systems use ionic silver, as described above, except for the clinic (\#7) which uses a household reverse osmosis system at the final point of use, and site \#5, which uses colloidal silver applied to a 1,100 I tank located on the rooftop, where the filtered water is stored. This is also the only gravity-fed system (i.e. water is pumped and filtered from cistern to elevated tank, and dispensed by gravity to taps). Other systems operate using a pump with a 20 I pressure tank, thus providing water on demand directly from the cistern. 
Adler, I; Campos, LC; Hudson-Edwards, KA; (2011) Converting rain into drinking water: Quality issues and technological advances. Water Science and Technology: Water Supply , 11 (6) 659 - 667.

Table 1. Rainwater harvesting systems used for study.

\begin{tabular}{|c|c|c|c|c|c|c|}
\hline ID & Community/sampling site & $\begin{array}{l}\text { Roof area } \\
\left(\mathrm{m}^{2}\right)\end{array}$ & $\begin{array}{c}\text { Consumption } \\
\text { (m³/year) }\end{array}$ & $\begin{array}{l}\text { Cistern } \\
\text { Type }\end{array}$ & $\begin{array}{l}\text { Cist. size } \\
\left(\mathrm{m}^{3}\right)\end{array}$ & $\begin{array}{c}\text { Roof } \\
\text { Conditions }\end{array}$ \\
\hline 1 & Rancho Nuevo Villa Guadalupe & 80 & 10.0 & TK & 5 & Clear \\
\hline 2 & San Antonio de la Joya & 82 & 11.6 & OG & 17 & Trees \\
\hline 3 & Don Juan & 49 & 8.0 & OG & 7.5 & Clear \\
\hline 4 & La Aurora & 60 & 8.8 & TK & 10 & Clear \\
\hline 5 & San Miguel Viejo - Classroom & 98 & 32.0 & OG & 45 & Trees, rocks \\
\hline 6 & San Miguel Viejo - Kitchen & 60 & 16.0 & UG & 17 & Bird nests \\
\hline 7 & Augustin Gonzalez - Clinic & 140 & NA & UG & 45 & Trees \\
\hline 8 & Augustin Gonzalez - School & 350 & 48.0 & UG & 80 & Debris, dust \\
\hline 9 & El Salitre & 200 & 30.0 & OG & 17 & Trees \\
\hline
\end{tabular}

Notes: Systems are all installed in schools in the respective communities, except for (\#7) which is in a rural clinic.

OG - Overground geomembrane; UG - buried/underground cistern with geomembrane liner; TK -prefabricated plastic tanks (5,000 I) with lids; NA - not available. 'Clear' refers to roofs without overhanging trees or debris.

Roofs are made of concrete, coated with an asphalt-based paint for waterproofing known by its brand name 'Fester' (manufactured by Henkel in Mexico). The only exception to this was site \#1, which has an asbestos roof. The overall conditions of each catchment surface were found to be highly variable. In some cases the waterproof coating was intact, while in others it looked worn and badly in need of repair.

To evaluate the treatment model described above, with the added aim of generating a set of recommendations for improvement, nine systems were monitored at different stages of the treatment/ purification process, for a number of water quality parameters (Table 2). Although the results obtained are preliminary, they give a good idea as to the overall performance, as well as the potential drawbacks that may need to be faced in future implementations of the technique.

\section{Sampling}

Samples were collected between April and June 2010 as part of a UCL-led research project. A total of 9 sites were analysed, with 3 distinct sampling points in each one, corresponding to the main stages of the treatment process:

1) Settling/first flush tank - from a valve located at the bottom of the tank, which is regularly used for cleaning and flushing.

2) Cistern - In overground tanks this was taken from a lower valve $(5-10 \mathrm{~cm}$ above the bottom) on the same line that leads to the pump and filters. In underground cisterns, it was taken from the suction of the pump, located roughly $20-30 \mathrm{~cm}$ over the bottom.

3) Drinking fountain taps (i.e. after filtration and silver ionization) - taken directly from the same taps where schoolchildren or other users consume the water.

In theory, the cistern should also contain a small concentration of silver ions, as there is some backflow from the pump to the cistern (see Figure 1). For all samples, outlets were let to run for about 1 min before collection. The parameters measured are classified as follows:

Field parameters. These were measured onsite and include temperature, $\mathrm{pH}$, conductivity and dissolved oxygen (DO). All of these parameters were checked again at the laboratory the same day, before starting microbiology tests. The methods used for each parameter are summarized in Table 2. Oxygen values were found to be very similar after collection in watertight jars and transport back to the laboratory, to those read directly in the field. A visual inspection of the colour and water quality was recorded on every reading, as well as the overall condition of the system. Users were interviewed regarding the operation and maintenance of the system, as well as community and public involvement in the project, which was found to be variable.

Local laboratory analyses. Measurements that required digestion or more sophisticated equipment were collected in sealed $250 \mathrm{ml}$ glass bottles $(500 \mathrm{ml})$ and transported refrigerated to the local laboratory, located 
Adler, I; Campos, LC; Hudson-Edwards, KA; (2011) Converting rain into drinking water: Quality issues and technological advances. Water Science and Technology: Water Supply , 11 (6) 659 - 667.

at the municipal wastewater treatment plant of San Miguel de Allende and operated by the local Water Authority (SAPASMA). COD was chosen for monitoring organic matter, which is expected in rainwater (Nolde 2007), since TOC equipment was not available. COD has been closely correlated to TOC in a number of studies (Dubber \& Gray 2010).

Microbiology. Samples for total coliform analyses were collected in commercially available sterile $100 \mathrm{ml}$ plastic bags, containing a capsule of sodium thiosulfate to remove traces of chlorine that may inactivate bacteria previous to measurement. These were analysed promptly upon arrival with membrane filtration and $24 \mathrm{~h}$ incubation, using Hach m-Colliblue broth. This method has been approved by the USEPA (Crane et al. 2006).

Table 2. Parameters evaluated and methods of analyses.

\begin{tabular}{|c|c|}
\hline $\mathrm{pH}$ & Orion Aplus portable PH/ISE Meter \\
\hline Conductivity & Portable ECTestr meter: low range (0 - 1900 $\mu S)$ \\
\hline Coliforms & Hach m-ColiBlue24® Broth (Membrane Filtration method) \\
\hline COD & Hach DR2800 Spectrophotometer \\
\hline Silver & Hach DR2800 Spectrophotometer \\
\hline Hardness/ Alkalinity & Aquachek 5-in-1 Water Quality test strips \\
\hline Dissolved Oxygen/ Temp. & Hach sensION 6 DO meter \\
\hline Cations (Ca, K, Mg, Na, P) & Jobin Yvon Ultima 2 ICP-OES \\
\hline Anions $\left(\mathrm{F}, \mathrm{Cl}, \mathrm{NO}_{3}, \mathrm{SO}_{4}\right)$ & Dionex 2000i Ion Chromatograph \\
\hline
\end{tabular}

ICP analyses. Cations and anions were analysed in the Wolfson Laboratory for Environmental Geochemistry at UCL-Birkbeck, UK. These samples were taken in $30 \mathrm{ml}$ watertight plastic containers. Cation samples were stabilized onsite using 1-2 drops of nitric acid $\left(\mathrm{HNO}_{3}\right)$, down to a $\mathrm{pH}$ value of about 2 . The samples were placed in a Styrofoam cooler and shipped to London upon conclusion of fieldwork. They were analysed on October 2010.

\section{Data analysis}

Due to a number of logistical constraints, it was not possible to take repeated measurements at each site. The data obtained was thus considered to be qualitative rather than an accurate measurement of efficiency. ANOVA and t-tests were performed to evaluate removal rates using Microsoft Excel, applying a log transformation for coliform counts. Samples were collected after a heavy isolated rainfall period in February 2010. Since this was in the middle of the dry season, most cisterns were empty or near empty. Thus, it can be safely assumed that all the samples come mostly from the same source. Given that quasi-identical treatment, filtering and storage materials are being used on all sites, the data set was combined to establish general trends of the system as a whole.

\section{RESULTS AND DISCUSSION}

\section{Field parameters}

Table 3 summarizes the main results obtained from field data for the 9 sites, evaluated along each point of the treatment system. As shown in Figure 2, COD drops significantly $(p=0.0026)$ with the first flush/ settling tank alone ( $77 \%$ reduction). A further $41 \%$ removal is achieved by the filtering treatment system, possibly aided by additional sedimentation occurring in the cistern itself. Evans et al. (2009) have also suggested the possibility of a beneficial micro-ecology in rainwater cisterns, whereby a host of bacteria may accelerate the degradation of organic matter and improve water quality, although this has not been verified in the present study.

Table 3. Summary of basic sampling parameters ${ }^{1}$

\begin{tabular}{ccccccc}
\hline \multirow{2}{*}{ Parameter } & $\begin{array}{c}\text { Settling Tank } \\
\text { Range }(\text { mean) }\end{array}$ & $\mathrm{N}$ & Range $($ mean) & $\mathrm{N}$ & $\begin{array}{c}\text { Drinking Tap } \\
\text { Range (mean) }\end{array}$ & $\mathrm{N}$ \\
\hline Temp $\left({ }^{\circ} \mathrm{C}\right)$ & $16.6-28.5(21.2)$ & 5 & $16.1-24(21.4)$ & 9 & $16-35(22.8)$ & 9 \\
$\mathrm{pH}$ & $6-6.7(6.4)$ & 5 & $6-7.3(6.6)$ & 7 & $6.3-7.1(6.8)$ & 6
\end{tabular}


Adler, I; Campos, LC; Hudson-Edwards, KA; (2011) Converting rain into drinking water: Quality issues and technological advances. Water Science and Technology: Water Supply , 11 (6) $659-667$.

$\begin{array}{ccccccc}\begin{array}{c}\text { Conductivity } \\ (\mu \mathrm{S} / \mathrm{cm})\end{array} & 80-170(108) & 5 & 40-150(83.3) & 6 & 60-150(110) & 5 \\ \mathrm{COD}(\mathrm{mg} / \mathrm{l}) & 10-76(47.9) & 7 & 3-25(11) & 7 & 2-18(6.4) & 7 \\ \mathrm{DO}(\mathrm{mg} / \mathrm{l}) & 2.6-4.1(3.5) & 4 & 2.8-4.7(3.8) & 5 & 1.9-3.7(2.8) & 4 \\ \text { Hardness }(\mathrm{mg} / \mathrm{l}) & 25-200(65.7) & 7 & 10-250(80.6) & 9 & 25-200(67.8) & 9 \\ \text { Alkalinity }(\mathrm{mg} / \mathrm{l}) & 40-180(65.7) & 7 & 10-240(77.8) & 9 & 20-240(73.3) & 9\end{array}$

1. Not all parameters were measured for each sampling point. This is reflected in the sampling frequency (N). For instance, some settling tanks were empty or had just been cleaned prior to sampling.

2. Range refers to minimum and maximum values for all samples collected.

Silver was found to be consistently lower than $5 \mathrm{ppb}$, which is the detection limit of the instrument used (Table 2) for all the samples evaluated. Readings were usually between 1 and $2 \mathrm{ppb}$, but cannot be relied upon given this detection limit. Lower concentrations can be detected by ICP-MS analysis, but samples must be analysed immediately after collection (APHA 2005). This was not possible, since no ICP-MS was available near the study site.

DO levels remained relatively low throughout the system (Figure 2), which is a likely consequence of the water being stored without much movement or aeration for several months. It is noteworthy, however, that the settling tanks with considerably more organic matter and visual contamination do not have lower DO levels. This may be due to the fact that settling tanks, being smaller and retaining foul waters from the first flushes, are cleaned and emptied more regularly than cisterns, which can potentially store rainwater for an entire year. Upon installation of the systems, users were advised to clean these tanks at least monthly, while cisterns only once a year.

Finally, $\mathrm{pH}$ was observed to remain at slightly acidic to neutral values (Figure 2). From the first point (settling tank) to the final point of use, conductivity also remained constant, with a significant drop in the cistern, possibly due to the greater dilution of total dissolved solids and their subsequent concentration in the filters and narrow pipes. Conductivity, hardness and bicarbonate alkalinity are considerably lower than in municipal well water (ESF 2006), as would be expected from rainwater, while displaying no significant variation throughout the treatment system.

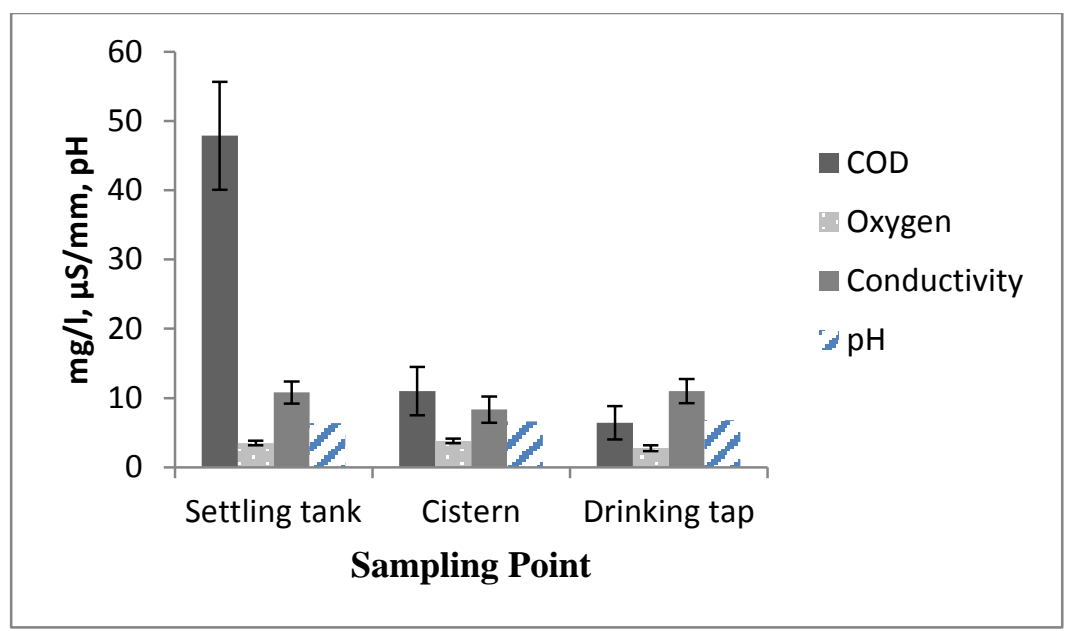

Figure 2. Comparison of selected field parameter means. SEM values shown in black line (except for $\mathrm{pH}$, where variation is too small to be represented). Note: Conductivity is shown in $\mu \mathrm{S} / \mathrm{mm}$.

\footnotetext{
Microbiology

Although the use of coliform bacteria as an indicator microorganism is controversial (Gleeson \& Gray 1996; Evans et al. 2007), it was utilized here for convenience due to its widespread acceptance. In line with the main aim of this study, total coliform counts were used in order to employ a consistent bacterial measurement throughout..
}

For each site, 3 samples were taken, corresponding to the treatment stages described above (settling tank, cistern, drinking tap). The only exception to this were the settling tanks where only 7 could be sampled, since the remaining 2 were empty, presumably for cleaning. Sites \#1, \#3 and \#4 showed zero coliforms on all samples, including in the settling tanks, which suggests a clean runoff not requiring disinfection or further 
Adler, I; Campos, LC; Hudson-Edwards, KA; (2011) Converting rain into drinking water: Quality issues and technological advances. Water Science and Technology: Water Supply , 11 (6) 659 - 667.

treatment. Mexican water quality guidelines require an absence of faecal coliforms for drinking water, allowing up to $2 \mathrm{CFU} / 100 \mathrm{ml}$ for total coliform counts (Secretaría de Salud 1994). Table 4 shows measured values for the rest of the sites, including efficiency of the settling tank and of the filtering/ silver ion system. With the exception of site \#9, all the systems showed a highly efficient disinfection rate, down to levels deemed acceptable by WHO standards, which suggest a more 'lax' (and thus realistic) target for rural water supply in developing countries (WHO 1997).

Site \#9 displayed an inordinately high bacterial load in the settling tank, which was not eliminated throughout the treatment process. The initial value of $2600 \mathrm{CFU} / 100 \mathrm{ml}$ was estimated by successive dilutions. Coliform counts in the cistern and at the final tap were probably lower, judging by the lower COD (Table 3) and better visual aspect of the water, yet were still too numerous to count without dilutions, in sharp contrast to all the other sites. In this particular case, a large fissure was observed on the lid of the geomembrane cistern which allowed debris and decaying organic matter to seep into the tank. Site \#6 also displayed a high number of coliforms in the initial stage, possibly due to a birds' nest found right on the downspout of the main gutter and overhanging trees on top of the roof. Nevertheless, coliforms were still substantially decreased by the settling tank alone (98\%), showing a thorough elimination down to drinking water standards after the purification system (Secretaría de Salud 1994).

Table 4. Total coliform counts for selected sites (CFU/100ml).

\begin{tabular}{lcccccc}
\hline \multicolumn{1}{c}{ Site No. } & 2 & 5 & 6 & 7 & 8 & 9 \\
\hline Settling Tank (ST) & 550 & 8 & 1650 & 119 & NA & $>2600$ \\
Cistern (CIST) & 6 & 3 & 26 & 17 & 3 & TNC \\
Drinking tap (DT) & 4 & 3 & 2 & 0 & 0 & TNC \\
\hline Removal due to settling $^{1}$ & $98.9 \%$ & $62.5 \%$ & $98.4 \%$ & $85.7 \%$ & & \\
Removal due to treatment $^{2}$ & $33.3 \%$ & $0.0 \%$ & $92.3 \%$ & $100 \%$ & $100 \%$ & \\
Total Removal $^{\text {The }}$ & $\mathbf{9 9 . 3 \%}$ & $\mathbf{6 2 . 5 \%}$ & $\mathbf{9 9 . 9 \%}$ & $\mathbf{1 0 0 \%}$ & $\mathbf{1 0 0 \%}$ & \\
\hline
\end{tabular}

1. Total coliform removal (\%) between settling tank and cistern (i.e. due to settling/first flush action)

2. Total coliform removal (\%) between cistern and drinking tap (i.e. due to filtering/silver ion system)

TNC - Too numerous to count.

The important reduction of indicator bacteria with the settling tanks $(p<0.05)$, which also act as first-flush devices, is consistent with the literature (Kus et al. 2010; Yaziz et al. 1989; Abbott et al. 2007). The same can be said for COD and organic matter in general. The combination of filters with silver ions is shown to be effective in performing the additional removal required. The failure of the system in the case of site \#9, where exceedingly high loads were found, a situation that can certainly recur in future installations, could imply that the purification system does not have the potency required for effective drinking water provision. However, this overlooks the fact that the Ag concentration used ( $<5 \mathrm{ppb})$ was much lower than that normally applied for effective disinfection, according to experiments done on a wide array of microorganisms (Landau 2007; Yahya et al. 1990), where concentrations are usually at least 10 times higher. In the latest guidelines for drinking water quality, the $\mathrm{WHO}$ concludes that $\mathrm{Ag}$ concentrations of up to $100 \mathrm{ppb}$ can be tolerated without risk, a value "under which no adverse health effects are observed" (WHO 2008). 
Adler, I; Campos, LC; Hudson-Edwards, KA; (2011) Converting rain into drinking water: Quality issues and technological advances. Water Science and Technology: Water Supply , 11 (6) 659 - 667.

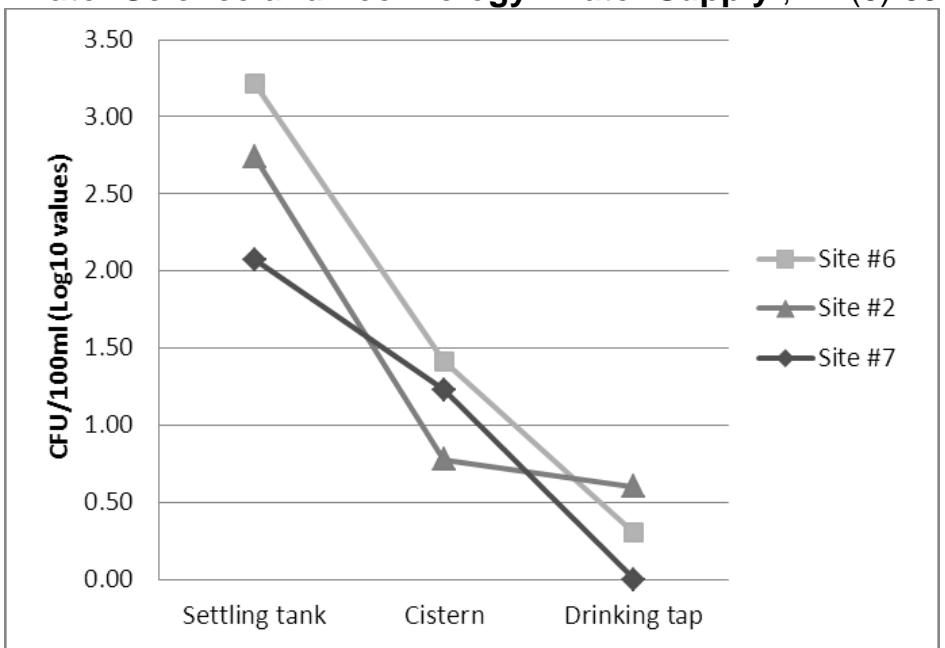

Figure 3. Total coliform removal efficiency for selected sites, in logarithmic values.

\section{Chemical Composition}

Assuming that all alkalinity is attributable to $\mathrm{HCO}_{3}$, the settling tank, cistern and drinking tap samples are all $\mathrm{Ca}-\mathrm{HCO}_{3}$ waters (Table 5). Their concentrations are typical of Mexican rainwaters (Baez et al. 2006), except that they have higher $\mathrm{pH}$. In general terms, concentrations of $\mathrm{Ca}, \mathrm{K}, \mathrm{Mg}, \mathrm{Na}, \mathrm{F}, \mathrm{Cl}, \mathrm{NO}_{3}$ and $\mathrm{SO}_{4}$ decline in passing from the settling tank to cistern to drinking tap, with the most significant decline from the settling tank to the cistern. These declines are likely due to either dilution or the precipitation of secondary minerals such as carbonates, which would have co-precipitated or sorbed the elements. The consistency in these patterns is different to that observed by Morrow et al. (2010), who documented higher degrees of element variability at different points in rainwater harvesting systems in Australia. All elements measured here are well below the limits set out by local drinking water standards (Secretaría de Salud 2000), with the exception of nitrate, which reaches values close to the $10 \mathrm{mg} / \mathrm{l}$ guideline in sites \#3, \#5 and \#6.

Table 5. Cation and anion compositions in $\mathrm{mg} / \mathrm{l}$.

\begin{tabular}{ccccccc}
\hline & Settling Tank & Cistern & \multicolumn{2}{c}{ Drinking Tap } \\
Cations & Range (mean) & $\mathrm{N}$ & Range (mean) & $\mathrm{N}$ & Range (mean) & $\mathrm{N}$ \\
\hline $\mathrm{Ca}$ & $4.17-12.44(9.75)$ & 4 & $0.85-16.45(7.58)$ & 5 & $4.82-16.01(9.93)$ & 5 \\
$\mathrm{~K}$ & $0.62-9.38(3.21)$ & 4 & $0.72-3.32(1.52)$ & 5 & $0.87-1.99(1.42)$ & 5 \\
$\mathrm{Mg}$ & $0.13-0.51(0.31)$ & 4 & $0.11-0.82(0.36)$ & 3 & $0.05-0.63(0.36)$ & 4 \\
$\mathrm{Na}$ & $0.34-19.37(5.26)$ & 4 & $0.19-9.44(3.23)$ & 5 & $0.51-10.73(5.17)$ & 5 \\
$\mathrm{P}$ & $0.03-0.16(0.08)$ & 4 & $0.02-0.06(0.04)$ & 3 & $0.010-0.014(0.012)$ & 2 \\
Anions & & & & & & \\
$\mathrm{F}$ & $0.18-0.25(0.22)$ & 4 & $0.07-0.54(0.23)$ & 5 & $0.09-0.58(0.27)$ & 5 \\
$\mathrm{Cl}$ & $1.34-4.01(2.52)$ & 4 & $0.63-2.52(1.48)$ & 5 & $0.45-6.17(2.26)$ & 5 \\
$\mathrm{NO}_{3}$ & $2.42-9.15(5.58)$ & 4 & $1.42-8.59(3.84)$ & 5 & $0.1-9.26(3.7)$ & 5 \\
$\mathrm{SO}_{4}$ & $5.68-13.6(9.58)$ & 4 & $2.04-9.77(4.51)$ & 5 & $3.07-10.24(6.16)$ & 5 \\
\hline
\end{tabular}

Based on the data collected it can be seen that in 8 out of 9 systems surveyed, the bacterial indicator and other elements measured were effectively reduced to safe levels for consumption. Total coliforms and COD in particular were found to reduce significantly throughout the system $(p<0.05$ and $p<0.001$, respectively). The only failure (Site \#9) was caused by an identifiable leak that allowed cross-contamination by seepage from outside the cistern. The excessive bacterial load created by situations such as these can probably be safely addressed by increasing the levels of silver in the water. The devices employed for this purpose were set at approximately $5 \mathrm{~V}$, which yield silver concentrations lower than $5 \mathrm{ppb}$ as described above. The equipment allows up to $20 \mathrm{~V}$ or more, thus allowing a four-fold increase whenever needed by simply turning up a dial. 
Adler, I; Campos, LC; Hudson-Edwards, KA; (2011) Converting rain into drinking water: Quality issues and technological advances. Water Science and Technology: Water Supply , 11 (6) 659 - 667.

It is unlikely that the disinfection levels obtained could have been achieved by using filtration alone. The pore sizes of conventional sediment cartridges and carbon filters allow most micro-organisms to pass through (WHO 2008). In fact, colonization of bacteria and recontamination is a common occurrence, given the large surface area and adsorption capacity of granular activated carbon (Bitton 1994). All the systems evaluated for this study had been in use for at least a year at the time of sampling, without any replacement of carbon cartridges, thus allowing biofilms to accumulate.

\section{CONCLUSIONS}

It can be concluded that the system with all its components, including settling tank, filters and silver ionizer, has the potential to provide quality drinking water from harvested rain as long as reasonable and routine maintenance is performed (i.e. flushing of settling tanks, roof cleaning, etc.), although more tests would need to be done in order to adequately determine this. The specific role of the silver ionizer also needs to be more accurately defined. Our research group is currently working on a laboratory-scale model to determine this, along with appropriate methods for improving the efficiency of the overall system. Furthermore, the first flush mechanism can be enhanced to allow for a better drainage or 'self-cleaning', avoiding stagnating water which increases the risk of contamination (Abbott et al. 2007; S. Ward et al. 2010). The importance of proper innovation and design in this regard cannot be overlooked.

\section{REFERENCES}

APHA, 2005. Standard Methods for the Examination of Water \& Wastewater 21st ed. Andrew D. Eaton et al., eds., American Public Health Association.

Abbott, S. et al., 2007. An evaluation of measures for improving the quality of roof-collected rainwater. In 13th IRCSA Conference. Sydney, Australia.

Amin, M.T. \& Han, M., 2009. Roof-harvested rainwater for potable purposes: Application of solar disinfection (SODIS) and limitations. Water Sci. Technol., 60(2), p.419-431.

Baez, A. et al., 2006. Rainwater chemical composition at two sites in Central Mexico. Atmospheric Research, 80(1), p.67-85.

Bitton, G., 1994. Wastewater Microbiology, New York: Wiley-Liss.

Crane, R. et al., 2006. EPA Approves New Test Procedures for the Analysis of Microbiological Pollutants in Wastewater and Sludge, Loveland, CO, USA.

Dubber, D. \& Gray, N.F., 2010. Replacement of chemical oxygen demand (COD) with total organic carbon (TOC) for monitoring wastewater treatment performance to minimize disposal of toxic analytical waste. Journal of environmental science and health. Part A, Toxic/hazardous substances \& environmental engineering, 45(12), p.1595-600.

Ecosystem Sciences Foundation [ESF], 2006. Well Water Quality in San Miguel de Allende: Results and Conclusions, Boise, ID.

Evans, C., Coombes, P., et al., 2007. Roof Harvested Rainwater - Indicator Organisms , Water Quality and Risk Assessment. In 13th IRCSA Conference. Sydney, Australia.

Evans, C.A. et al., 2009. Extensive bacterial diversity indicates the potential operation of a dynamic microecology within domestic rainwater storage systems. The Science of the total environment, 407(19), p.5206-15.

Evans, C.A., Coombes, Peter J, et al., 2007. Identifying the major influences on the microbial composition of roof harvested rainwater and the implications for water quality. Water Science and Technology, 55(4), p.245-253.

Fewtrell, L. \& Kay, D., 2007. Microbial quality of rainwater supplies in developed countries: a review. Urban Water Journal, 4(4), p.253-260. 
Adler, I; Campos, LC; Hudson-Edwards, KA; (2011) Converting rain into drinking water: Quality issues and technological advances. Water Science and Technology: Water Supply , 11 (6) 659 - 667.

Gerba, Charles \& Thurman, R., 1989. The molecular mechanisms of copper and silver ion disinfection of bacteria and viruses. Critical Reviews in Env. Sci. and Tech., 18(4), p.296-315.

Gleeson, C. \& Gray, N., 1996. Coliform Index and Waterborne Disease, London: Spon Press.

Gould, J., 1999. Is rainwater safe to drink? A review of recent findings. In Proceedings of the 9th International Rainwater Catchment Systems Conference, July 6-9, 1999. Petrolina, Brazil.

Gould, J. \& Nissen-Petersen, E., 1999. Rainwater Catchment Systems for Domestic Supply: Design, Construction and Implementation, Intermediate technology publications.

Kus, B. et al., 2010. Analysis of first flush to improve the water quality in rainwater tanks. Water science and technology, 61(2), p.421-428.

Landau, U., 2007. Bactericidal and Oligodynamic Action of Silver and Copper in Hygiene, Medicine and Water Treatment, Finishing Publications Ltd.

Lansdown, A.B.G., 2006. Silver in health care: antimicrobial effects and safety in use. Current problems in dermatology, 33, p.17-34.

Lye, D.J., 2002. Health risks associated with consumption of untreated water from household roof catchment systems. Journal of the American Water Resources Association, 38(5), p.1301-1306.

Lye, D.J., 2009. Rooftop runoff as a source of contamination: a review. The Science of the total environment, 407(21), p.5429-34.

Meera, V. \& Ahammed, M., 2006. Water quality of rooftop rainwater harvesting systems: A review. Journal of Water Supply: Research and Technology-AQUA, 55(4), p.257-268.

Mitch, W.A. et al., 2003. N-Nitrosodimethylamine (NDMA) as a Drinking Water Contaminant: A Review. Environmental Engineering Science, 20(5), p.389-404.

Morrow, A.C., Dunstan, R H \& Coombes, P J, 2010. Elemental composition at different points of the rainwater harvesting system. Science of the Total Environment, 408(20), p.4542-4548.

Nolde, E., 2007. Possibilities of rainwater utilisation in densely populated areas including precipitation runoffs from traffic surfaces. Desalination, 215(1-3), p.1-11.

Pabon, C., 2009. Study pours cold water on solar disinfection. Science and Development Network, 31/8/09. Available at: http://www.scidev.net/en/news/study-pours-cold-water-on-solar-disinfection.html [Accessed November 26, 2010].

Secretaría de Salud, 2000. Modificacion a la Norma Oficial Mexicana NOM-127-SSA1-1994, Salud ambiental. Agua para uso y consumo humano, Mexico.

Secretaría de Salud, 1994. Norma Oficial Mexicana NOM-127-SSA1-1994 "Salud Ambiental, Agua para uso y consumo humano-limites permisibles de calidad y tratamientos a que debe someterse el agua para su potabilizacion," Mexico.

Signor, R., Ashbolt, N. \& Roser, D., 2007. Microbial risk implications of rainfall-induced runoff events entering a reservoir used as a drinking-water source. Journal of Water Supply: Research and Technology AQUA, 56(8).

Simmons, G. et al., 2001. Contamination of potable roof-collected rainwater in Auckland, New Zealand. Water research, 35(6), p.1518-24.

WHO, 1997. Guidelines for Drinking-Water Quality, Vol. 3: Surveillance and control of community supplies 2nd ed., Geneva: World Health Organization. 
Adler, I; Campos, LC; Hudson-Edwards, KA; (2011) Converting rain into drinking water: Quality issues and technological advances. Water Science and Technology: Water Supply , 11 (6) 659 - 667.

WHO, 2008. Guidelines for Drinking-water Quality 3rd ed., Geneva: World Health Organization.

Ward, S., Memon, F.A. \& Butler, D., 2010. Harvested rainwater quality: The importance of appropriate design. Water Sci. Technol., 61(7), p.1707-1714.

Xie, Y., 2004. Disinfection Byproducts in Drinking Water: Formation, Analysis, and Control, CRC Press.

Yahya, M. et al., 1990. Disinfection of Bacteria In Water Systems by Using Electrolytically Generated Copper Silver \& Reduced Levels of Free Chlorine . Canadian Journal of Microbiology, 36, p.109-116.

Yaziz, M.I. et al., 1989. Variations in rainwater quality from roof catchments. Water Research, 23(6), p.761765.

\section{ACKNOWLEDGEMENTS}

The authors would like to thank the Water Authority of San Miguel (SAPASMA), the helpful personnel at the municipal wastewater treatment plant, and the local Environment \& Ecology Dept. (DMAE), in particular Julio Bernal, Denia Gonzalez and Ernesto Aguilera, for making this study possible. We are also grateful to Mexican artist Jimena Cancino, who offered the drawings. 